\title{
EATING HABITS: ARE WE SAFE TO CONSUME FRESHWATER PUFFER FISH FROM THE AMAZON REGION IN BRAZIL?
}

Colomesus asellus (Müller and Troschel, 1848) is an Amazonian freshwater puffer fish which is occasionally sold by aquarists in Brazil. Apart from the popular knowledge that it is poisonous, this species is poorly known by science, since there are not studies concerning its biology, behavior, ecology and toxicity.

During a meeting of the International Society on Toxinology, which took place in Paris, France, we found out that this species has been sold in Japan by aquarists and the Japanese scientists started to perform studies using these commercial specimens bought in shopping centers at Ueno Station, Tokyo. At this time we should ask, how do these fish from Amazon get to the shopping centers in Japan?

This year we are publishing a paper dealing with $C$. asellus, a toxic puffer fish from the Amazonas State, Brazil. The work has involved collaboration with J. S. Oliveira from the Biosciences Institute, University of São Paulo, USP, São Paulo, Brazil; S. C. R. Fernandes, O. R. Pires Jr and C. A. Schwartz from the Biology Institute, University of Brasília, Unb, Brasília, Brazil; and C. Bloch Jr. and J. A. T. Melo from the National Center for Genetic Resources and Biotechnology Research, CENARGENEMBRAPA, Brasília, Brazil. In addition, we used four different techniques - mouse bioassay, ELISA, HPLC, and mass spectrometry. We evaluated toxicity in extracts of twenty-four $C$. asellus specimens collected at Tocantins River in the town harbor of Cametá, Pará State, Brazil, and identified for the first time the components responsible for its toxicity as being different from tetrodotoxin (TTX), the well-known toxin isolated from puffer fish.

The T20G10 monoclonal antibody raised against TTX and used as an indirect competitive enzyme immunoassay showed very low affinity for $C$. asellus body extracts, indicating that TTX and its analogues are not the main toxic components of the extracts. This antibody was effective in detecting the presence of TTX in a total extract of Sphoeroides spengleri, which is one of the most toxic puffer fish found in the Atlantic Ocean Coast. Extracts of $C$. asellus were toxic when intraperitoneally administered into mice. The HPLC profile showed no traces of TTX but only the presence of paralytic shellfish poisons (saxitoxin - STX, gonyautoxin 2 - GTX 2, and gonyautoxin 3 - GTX 3). These toxins were also confirmed by electrospray ionization mass spectrometry.

As known, puffer fish may cause a characteristic clinical poisoning with a high mortality rate, but in Japan and China it has been considered a delicacy. In Occidental countries, puffer fish are only sporadically consumed and have been involved in several human poisonings, mainly by the species belonging to the genus Sphoeroides. Toxinological studies of $S$. spengleri have been recently reported by Freitas et al. (1) and Oliveira et al. (4). The poison found in the flesh of freshwater puffers may be composed of TTX or STX and its analogues; the predominant toxin being dependent on the species. These guanidinium toxins induce paralysis by their action on many excitable cells (nerves and muscles) through binding to the site 1 of the voltage-gated sodium channels, blocking their pores. Correct identification whether which toxin is responsible for this action when using an extract of a 
determined puffer fish is not always a simple task because both toxins (STX and TTX) bind to the same site on excitable membranes. For example, Tetraodon fangi, the Thailand freshwater puffer involved in some food poisonings in humans, was first reported to mainly possess TTX as its poison. Later, however, the major toxins of this fish were identified as STXs. Furthermore, other freshwater puffers such as Tetraodon leiurus complex and T. suvatii from Thailand, and Tetraodon cutcutia and Chelonodon patoca from Bangladesh may possess mainly paralytic shellfish poison (PSP) toxins (such as STX, neo-STX, decarbamoyl-STX, GTX 2, GTX 3, and decarbamoyl-GTX 2 and 3).

There are 185 species of puffer fish in the family Tetraodontidae, distributed in 28 genera. In the genus Colomesus, there are only two species described and both occur in Brazil: $C$. asellus (Amazon puffer fish) is an exclusively freshwater fish living in the Amazon Basin, and C. psittacus (Banded puffer) inhabits brackish waters at the Brazilian Northeast Coast estuaries. Sawaya (4) in 1966 reported in "Memórias do Instituto Butantan" that $C$. psittacus has an edible flesh and a very toxic liver, but its toxins and toxicity were not studied. More information on $\mathrm{C}$. asellus is now being published (2). Since the composition of toxins of the genus Colomesus was completely unknown, we performed the indirect competitive inhibition enzyme immunoassay (ICEIA) and HPLC analysis for TTXs, suspecting that $C$. asellus could accumulate this toxin and its derivatives. Following this, analyses for PSPs were also performed. The T20G10 MAb-TTX was employed in the ICEIA to detect TTX in $C$. asellus whole body extracts. Competitive inhibition curves were obtained from a standard curve of TTX, an extract from Sphoeroides spengleri, together with 6 extracts of $C$. asellus. The results demonstrated very high sensitivity, which was confirmed by the lowest detection limit of TTX as close to $0.1 \mathrm{ng} / \mathrm{ml}(\sim 0.00041 \mathrm{MU})$. The toxins in $C$. asellus extracts showed very low affinity in binding to the MAb-TTX, demonstrating that TTX is not the main toxic compound in these fish.

It has been reported that some species of puffer fish may accumulate both STX and TTX, and sometimes only the association of more than one chemical technique, such as HPLC and mass spectrometry, may accurately discriminate these two toxins. In the case of $C$. asellus, there was no evidence for TTX and its derivatives by both HPLC and mass spectrometry. Therefore, our results clearly demonstrated that saxitoxin (STX) is the main toxic component of $C$. asellus. The presence of STX in $C$. asellus extracts was confirmed by mass spectroscopy.

Considering the origin of the toxins, it is well-known that puffer fish do not produce TTX and its derivatives by itself; instead, the production is caused by various species of bacteria living in a symbiotic association with these fish or acquired in the food chain. In marine environment, STXs, which cause PSP, are produced by some species of dinoflagellates of the genus Alexandrium (Gonyaulax). It is also known that some xanthid crabs, horseshoe crabs and marine snails may possess PSP toxins, not associated with dinoflagellates. In freshwaters, certain species of cyanobacteria are involved in the production of these toxins. Although we did not investigate the possible bacterial source of toxins present in $C$. asellus tissues, this cannot be ruled out because $C$. asellus is an exclusively freshwater puffer. In conclusion, $C$. asellus, like other freshwater puffer fish, accumulates STX, although no NeoSTX was present in our samples.

In Brazil, some marine puffers are sporadically consumed by the local population, and poisoning cases were reported. In spite of there being no reports of food poisonings or even consumption of freshwater puffers by people in the Amazon 
region, we strongly recommend that consumption of the Brazilian puffer fish $C$. asellus should be avoided.

\section{REFERENCES}

1 FREITAS, JC., RANGEL, M., OLIVEIRA, JS., ZAHARENKO, AJ., ROZAS, E. An outline on marine toxinology studies in the Brazilian coast. Comm. Toxicol., 2003, 9, 1-22.

2 OLIVEIRA, JS., FERNANDES, SCR., SCHWARTZ, CA., BLOCH, C., MELO, JAT., PIRES, OR., FREITAS, JC. Toxicity and toxin identification in Colomesus asellus, an Amazonian (Brazil) freshwater puffer fish, Toxicon, doi:10.1016/j.toxicon.2006.04.009

3 OLIVEIRA, JS., PIRES JUNIOR, OR., MORALES, RAV., BLOCH JUNIOR, C., SCHWARTZ, CA., FREITAS, JC.. Toxicity of puffer fish - Two species (Lagocephalus laevigatus, Linaeus 1766 and Sphoeroides spengleri, Bloch 1785) from the Southeastern Brazilian Coast. J. Venom. Anim. Toxins incl. Trop. Dis., 2003, 9, 76-88.

4 SAWAYA, P., Toxic marine invertebrates - venomous and noxious fishes of freshwater. Mem. Inst. Butantan, 1966, 33, 31-34.

\section{CORRESPONDENCE TO:}

JOSÉ CARLOS DE FREITAS, Instituto de Biociências, Universidade de São Paulo, São Paulo, Brasil. Email: ifreitas@usp.br 